\title{
Albanian Economic Model Facing the Global Recession
}

\author{
Alqi Naqellari \\ Lecturer in Mediterranean University in Tirana \\ U. "Ismail Qemali" Vlora, Albania \\ alqinaqellari@gmail.com \\ Altin Hoti \\ Dean, University “Luarasi” Tirana, Albania \\ altin.hoti@yahoo.com \\ Jeton Shaqiri \\ Lecturer in IUS, Macedonia \\ j.shaqiri@eust.edu.mk
}

\section{Doi:10.5901/ajis.2013.v2n3p27}

\begin{abstract}
The Albanian economy after the 90'S entered in the tracks of the market economy. Entering into a new phase or a new economic system did not come as a result of an evolution or evolutionary process moving from feudalism to capitalism and from capitalism in its highest stage in imperialism but as a result of a revolutionary process ${ }^{1}$ which was followed by the overthrow of the socialist system. So Albanian economy moved from a fully centralized to a decentralized system based on private property and free initiative. This passage was made through a most constrained and not gradual passing. In this shift there are many positive but also negative issues. These advantages and disadvantages were also reflected in the attitudes of this economy facing the world global recession. In this section we will analyze the Albanian economic model facing global recession in 2008 and in the following years. We will perceive the economic model through the degree of privatization of economic factors, and not by the rate of application of political instruments to achieve macroeconomic indicators. We will treat the mentioned ones in light of Classical and Keynesian theory.
\end{abstract}

Keywords: Model economic, fiscal and monetary policy, styptic and expansionist policy, export-import, exchange rate, agriculture, trade, services, economic growth, unemployment, etc.

\section{Introduction}

In Albania before the 90s the state property was prevailing. Private property was not known while parastatal properties existed in the form of cooperative property, the epitome of which were agricultural cooperatives. In this way, in this period of time there existed the centralized course of the economy under the State Unique Plan. The concepts of market economy as inflation and unemployment were unknown.

Thus, analysis of these indicators for this period is irrelevant. In this economy everything planned and implemented by state, ranging from sectors of the real economy and to the financial services field.

Economy belonging to this period had a defined structure and did not undergo the laws of market economy. This happened because the market itself lacked. His absence eventually eliminated competition. Albanian economy was largely based on two main branches, industry and agriculture.

Structure of branches in Albania's economy has been as follows:

$\begin{array}{lll}\text { Composition of agricultural and industrial production in \% for 1975-1982 (with the prices of 1981) } \\ \text { Industry } & 64.8 & 69.8 \\ \text { Agriculture } & 35.2 & 30.2 \\ \text { Total } & 100 \% & 100 \%\end{array}$


The structure of agricultural production (1983)

$\begin{array}{lr}\text { Agriculture } & 73.5 \% \\ \text { Livestock } & 26.5 \% \\ \text { Total } & 100 \%\end{array}$

Total social product in $\%$ for $1975-1990^{1}$

$\begin{array}{llll} & 1975^{2} & 1980 & 1990 \\ \text { Total social product } & 100 & 100 & 100 \% \\ \text { Industry } & 57 & 43 & 58.4 \\ \text { Agriculture, Forestry } & 25.9 & 23.3 & 25 \\ \text { Construction } & 8.5 & 9.2 & 8.2 \\ \text { Transport, Comunication } & 8.6 & 2.7 & 2.6 \\ \text { Domestic Trade } & \mathrm{X} & 2.3 & 2.3 \\ \text { Foreign Trade } & \mathrm{X} & 2.2 & 2.2 \\ \text { Others } & \mathrm{X} & 17.3 & 1.3\end{array}$

\begin{tabular}{lcc}
\multicolumn{3}{l}{ Total industrial production(State sector) by branches(at the prices of $\mathbf{1 9 8 6}$ year) } \\
& 1980 & 1990 \\
Total industrial production & $100 \%$ & $100 \%$ \\
Foodstuffs industry & 25.5 & 25.5 \\
Light industry & 15.5 & 19.1 \\
Engineering industry & 12.5 & 14.6 \\
Copper industry & 6.4 & 7.1 \\
Oil and bitum industry & 9.3 & 5.1 \\
Chemical industry & 4.7 & 5.3 \\
Building materials industry & 7.8 & 5.5 \\
Timber and paper industry & 5.8 & 5.1 \\
Others & 12.5 & 12.7
\end{tabular}

Balance of production, usage and export of energy(1990)

$\begin{array}{lc}\text { 1. Total sources } & 100 \% \\ \text { - Oil and Gas } & 49 \% \\ \text { - Coal and Bituminous gravel } & 26.5 \\ \text { - Firewood } & 10.5 \\ \text { - Hydroenergy } & 14 \\ \text { 2. Usage in place } & 94 \\ \text { 3. Export } & 6 \%\end{array}$

As seen above the economy was mainly centered on the branch of industry, in production of food industry, of light and mechanical industry. In agriculture it was focused on agricultural production with $73.5 \%$ and $27.5 \%$ on livestock. This structure did not take into account the market but was taking into account the principles of socialist planning, as "support to its own forces, proletarian politics in the first plan, democratic centralism and the line of people.." Implementation of such a policy ignored the forces of economy, market and the free initiative. Lack of market, of free initiative, termination of cooperation with the outside world in the field of investments and other factors led to the Albanian economy to fail. After this failure it began its path toward a market economy.

After the 90's theory "0" issued in that period of time and after that "the blank check" lead to that condition that workers were breaking stealing almost material base and facilities created in dozens of years by that system. What remained was a destroyed economy, the closed mines, semi ruined or ruined enterprises. Companies that were not destroyed had amortized tools for production and a very backward technology level. Agriculture inherited a destroyed 
system of irrigation and drainage. The mechanical tools were outdated not effective. New workforce left from Albania to neighboring countries. Our economy in this condition was introduced in the privatization process which continues even today.

\subsection{The content of the material}

1. The process of privatization of the Albanian economy after the 90's.

2. The structure of the Albanian economy after the 90's and the impact on makroeconomic indicators.

3. Exports- Imports.

4. Classic- Keynesian Model and the effect of implementation of macroeconomic indicators.

5. Effects of Policy Instruments in terms of the Albanian Economic Model for the realization of macroeconomic indicators.

6. The consequences of fiscal policy in economy.

\section{The Process of Privatization of the Albanian Economy after the 90's.}

Major reforms in Albania were mainly focused on the area of legality. Were adopted hundreds of laws that belonged to a market economy where private property rules. Drafting the legal framework of a market economy preceded the privatization process. In these years started the process of privatization of the state economy and state money, the cooperative one. Land reform was realized. Land was spread to owners and its users based on Law 7501 dated 19.07.1991. The main aim was to pass state property into private property and government through this process to ensure as much revenue for the budget coffers that was empty.

In the process of privatization we distinguish two periods.

The first period that covers the years 1993-1999, where privatization receipts have been lower. Those were related with the privatization of entities of the marketing of goods in towns and villages spread throughout the country's territory.

The second period covers the years 2000-2010, during which the privatization of some very important services got possible, which by that time were provided by the state.

In 2000 , privatization obtained 8.9 billion, through which was financed $22 \%$ of the budget deficit. In 2000 , revenues were lower than current costs. In this year the National Commercial Bank was as well privatized.

In 2001, privatizations were increased by $43 \%$ and financed 30\% of the Budget deficit while 2002 and 2003 had a much lower average.

2004 again showed high income from privatizations. Additionally, year 2004 relates to the privatization of the former Savings Bank, which provided some coping of a part of the deficit and public debt reduction.

In 2005 and 2006 no significant privatizations were carried out.

Albtelecom was privatized in 2007.

In 2008 privatization revenues fell by 58\%. It was now the turn of ARMO Company to be transferred to the private sector.

The year 2009 marks the highest point of the proceeds from privatizations. About 25 billion lek served to finance the deficit and obviously the sale of $76 \%$ of the shares of the Poerator of Allocation System was the main event of the year.

In 2010, was privatized former Hotel DAJTI by the Bank of Albania for 30 million euros.

The year 2011 also draws attention to predictions associated with privatization. Privatizations this year should reach up to 300 million lek, a modest amount of money compared with previous years. 1280 state facilities came under the process of privatization. The list includes not only state-owned enterprises, but as well shares still owned by the Albanian state after privatization. It may be mentioned shares at AMC, Albtelekom, former DSO, etc.. With a simple calculation, their whole exceeds several times the amount of 300 million estimated for this year.

In 2012 privatization of hydropower of Lanabregas from Water supply Enterprise of Tirana. The continuation of privatization and concessions in the field of fuel. It is intended to privatize some mid-level plants as well.

Albanian economic model that was targeted after the 90's and still continues to be a target is based on total privatization. This privatization has led to the Albanian economy is based entirely on the private sector. With this privatization the state was stripped by the ownership and was avoided as a competitive entity in the field of market.

This economic model that was applied by Albanian Governments in our opinion was not right. They went from a completely centralized socialist system to a new system completely decentralized. The government with this action took 
these attributes to itself as a strong competitor in the market as an active subject, not only in the field of drafting and approving of laws but also in the field of economy. Maintaining strategic sectors as government property would not turn the system but would push it forward. A clear example is the Chinese economy where state sector procedes the private sector in many areas, particularly in the field of inventions and rationalization. Privatization should not be seen according to our discretion as a way to fill the coffers of the government but as a process to place in service the economy, which failed due to continuous excessive centralization.

State with privatization of such strong sectors as banking sector, oil sector, telephony sector, military sector etc., drew amounts that didn't pass 600 million dollars. Time showed that if there were not privatized these sectors, the income generated from them would have been higher, so the macroeconomic indicators such as Gross Domestic Product, unemployment rate, inflation, etc. Only assets of the Savings Bank from Raifaisenit for a very short period of reassessment almost doubled.

We are not speaking here just for the moment the income obtained from the sale of assets of the Albanian economy but also for consequences they brought in this economy in the coming years. The negative consequences that brought the total privatization in all fields have been great. So only in the field of bank the privatization of the Savings Bank took off the opportunity to not only become a strong competitor in the market but also the possibility of supporting sectors such as agriculture and livestock sectors that are less credit in the economy despite the roughly Albanian $20 \%$ of GDP. The Central Bank took the opportunity to have a strong arm in the implementation of its monetary policy.

\section{The Structure of the Albanian Economy after the 90's and the Impact on Makroeconomic Indicators}

The structure of the Albanian economy was admitted to spontaneity of the market economy. In this way it changed significantly from that of years when ruled the state unique plan. In 2010 besides some other macroeconomic indicators, it is presented as follows:

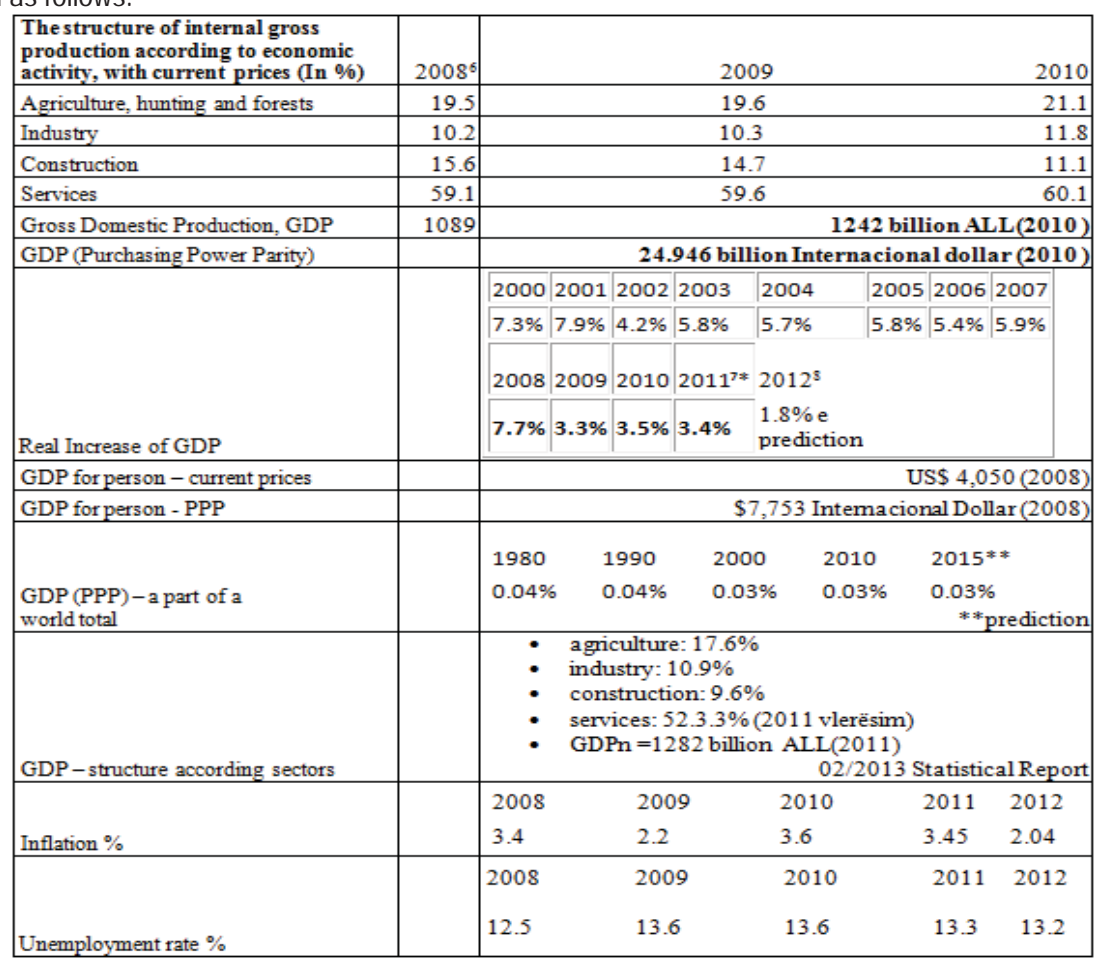

${ }^{3}$ U.S. Department of Energy - Country Report on Albania

${ }^{4}$ Bank of Albania (official site)

${ }^{5}$ Gross domestic product by economic activities. 1996-2011 at current prices, in lillions ALL. Source:INSTAT 
The data show that compared with 90's structure we have substantial changes. The economy from agricultural-industrial direction passed in farming services which has emerged services and the construction sector. Changing of the structure is determined by the specific conditions and market demands of domestic and foreign market. An important place in the sector of services takes tourism, transport, hotels, motels, etc..

Changing the structure of domestic production has its own implications on economic growth. This is because it does not rely on centralized management but on the request, on the market. There has been a market that has determined the structure of production. No matter the possibility of the influence of other factors worth mentioning that in overall we have economic growth but compared to the possibilities, with the presence of the factors that figure is still low, especially in the last three years which has fallen below $4 \%$. Albanian economic growth could be even higher if there would be a more pragmatic approach of bodies that develop and implement policy instruments in achieving macroeconomic indicators. A more realistic approach to the world situation of the Central Bank and of the Government will do to change their policies in the right direction and economic growth was higher. We not only look at the real economic growth at nominal GDP growth (because inflation rate has not had any significant impact on the pace of the increase of nominal GDP with its real) or real GDP but also other indicators where one of important ones is the unemployment rate.

If we refer to the INSTAT data we almost have stability in its fall in the minimum after the comma. For nearly 10 years it has fallen no more than $3 \%$, while the economic growth has been on average higher than $4 \%$. In these two figures we have a discrepancy that suggests that elements of GDP grew faster than ones that do not impact on the decline in the unemployment rate. So are increasing indications that impact on demand in the short term and not in long terms. This is mostly associated with exactly with BQ politics and Government applied in this period that coincides with the global recession.

If we refer to the Central Bank data we will see that we don't have notable changes in the growth of monetary aggregates as monetary base, money out off bank, $M_{1}$ and $M_{2}$ from 2008 to 2011. Nominal growth of these indicators is the symbolic expression of GDP growth since the last one is an expression of aggregate demand growth. If production increases, it is associated with the growth of aggregate demand that reflects the money in circulation. So in this respect we can say that economic growth is low and below the real possibilities of the Albanian economy. In this way the applied economic model has failed to provide the potential maximum of the real economic growth.

\section{Exports- Imports}

Foreign trade got a great burst, export-import. This is due to the fact that a good part of the infrastructure created till the 90's had been burned as in the field of agriculture as well as in industry. After the 90's imports were many times greater than exports. About 250 thousand tons of grain were imported to feed the population, oil, rice, sugar, fuel, chemicals, etc.. In 2009 the import-export ratio was 4/1. In 2011 imports were EUR 3,647 billion while exports 1.405 billion euros in the ratio $1 / 2.6$. For the past four years exports and imports have been as follows:

\subsection{Exports acoording to SITC 6 (in million euro)}

\begin{tabular}{|c|c|c|c|c|c|c|c|c|c|c|}
\hline Years & $\begin{array}{c}\text { Total } \\
2+3+4+5+6+7+8+9+10+11\end{array}$ & $\begin{array}{c}\text { Food } \\
\text { and } \\
\text { living } \\
\text { animals }\end{array}$ & $\begin{array}{c}\text { Beverage } \\
\text { and } \\
\text { tobacco }\end{array}$ & $\begin{array}{c}\text { Processed } \\
\text { materials }\end{array}$ & Fuel & $\begin{array}{c}\text { Animal } \\
\text { and } \\
\text { vegetable } \\
\text { fats }\end{array}$ & $\begin{array}{c}\text { Chemical } \\
\text { products }\end{array}$ & $\begin{array}{c}\text { Processed } \\
\text { goods }\end{array}$ & $\begin{array}{c}\text { Machinery } \\
\text { and } \\
\text { equipement }\end{array}$ & $\begin{array}{c}\text { Other } \\
\text { processed } \\
\text { goods }\end{array}$ \\
\hline 2008 & 917.5 & 32.3 & 2.6 & 108.3 & 81.9 & 0.2 & 10.4 & 232.3 & 38 & 411.6 \\
\hline 2009 & 750.7 & 36 & 3.4 & 81.2 & 90.8 & 0.3 & 12.6 & 136.6 & 34.8 & 355.6 \\
\hline 2010 & 1171.5 & 42.4 & 4.5 & 135.6 & 210.9 & 0.8 & 11.2 & 288 & 49.2 & 428.8 \\
\hline 2011 & 1405.5 & 48 & 4.1 & 147.7 & 297.6 & 1.7 & 18.8 & 354.1 & 56.4 & 477.1 \\
\hline
\end{tabular}

In 2012, 36\% of exports come from minerals, $29 \%$ from textiles- footwear and $19 \%$ from material. Three voices occupy over $84 \%$ of total exports 7 . 


\subsection{Import of goods according to SITC ${ }^{8}$ (in million euro)}

\begin{tabular}{|c|c|c|c|c|c|c|c|c|c|c|}
\hline Years & $\begin{array}{c}\text { Total } \\
2+3+4+5+6+7+8+9+10+11\end{array}$ & $\begin{array}{c}\text { Food } \\
\text { and } \\
\text { living } \\
\text { animals }\end{array}$ & $\begin{array}{c}\text { Beverage } \\
\text { and } \\
\text { tobacco }\end{array}$ & $\begin{array}{c}\text { Processed } \\
\text { materials }\end{array}$ & Fuel & $\begin{array}{c}\text { Animal } \\
\text { and } \\
\text { vegetable } \\
\text { fats }\end{array}$ & $\begin{array}{c}\text { Chemical } \\
\text { products }\end{array}$ & $\begin{array}{c}\text { Processed } \\
\text { goods }\end{array}$ & $\begin{array}{c}\text { Machinery } \\
\text { and } \\
\text { equipement }\end{array}$ & $\begin{array}{c}\text { Other } \\
\text { processed } \\
\text { goods }\end{array}$ \\
\hline 2008 & 3570.2 & 424.6 & 112.8 & 74.4 & 573.6 & 51.6 & 346.7 & 848.6 & 783.8 & 354.2 \\
\hline 2009 & 3248.8 & 395.1 & 123.8 & 95.7 & 382.6 & 39.2 & 362.5 & 811.9 & 741.9 & 296 \\
\hline 2010 & 3474.1 & 441.7 & 143.3 & 63.3 & 479.2 & 41.2 & 387.3 & 913.5 & 673.5 & 331 \\
\hline 2011 & 3905.3 & 473.7 & 127.9 & 55.9 & 683.4 & 49.3 & 412.1 & 968.8 & 784.5 & 349.6 \\
\hline
\end{tabular}

In 2012 six voices occupy over $90 \%$ of imports, minerals occupy $20 \%$, food $18 \%$, chemical products $12 \%$, machinery $18.3 \%, 13 \%$ building materials and textiles-shoes $9 \% 9$.

The data show clearly that there are two tendencies.

First, reduction of export-import ratio from 1/3.9 in 2008 01.02.77 2011. Exports in the last 4 years have grown by $53.2 \%$ and imports by $9.3 \%$. Significant changes in the structure of exports as well as in imports. The exports of fuels is increased by 3.6 times from 2008 to 2011, the goods and processed materials, etc. by 147\%. Fuel imports are increased by only $19 \%$ while the processed goods and materials is increased by $10 \%$.

\subsection{Countries in which Albania exports its products ${ }^{10}$ :}

\begin{tabular}{|c|c|c|c|c|c|c|c|c|c|c|c|c|}
\hline Years & $\begin{array}{c}\text { Total in } \\
\text { million euro }\end{array}$ & $\begin{array}{c}\text { Countries of } \\
\text { UE }\end{array}$ & $\%$ & $\begin{array}{c}\text { Countries of UE } \\
\text { (new member) }\end{array}$ & $\%$ & $\begin{array}{c}\text { Bul } \\
\text { garia }\end{array}$ & $\%$ & $\begin{array}{c}\text { Total } \\
\text { UE \% }\end{array}$ & $\begin{array}{c}\text { Balkan } \\
\text { countries }\end{array}$ & $\%$ & $\begin{array}{c}\text { Others countries } \\
\text { of the world }\end{array}$ & $\%$ \\
\hline 2008 & 917.5 & 715.7 & $\mathbf{7 8 . 0}$ & 14.4 & $\mathbf{1 . 6}$ & 6.6 & $\mathbf{4 5 . 8}$ & $\mathbf{7 9 . 6}$ & 143.2 & $\mathbf{1 5 . 6}$ & 44.2 & $\mathbf{4 . 8}$ \\
\hline 2009 & 750.6 & 576.2 & $\mathbf{7 6 . 8}$ & 10.1 & $\mathbf{1 . 3}$ & 4.7 & $\mathbf{4 6 . 5}$ & 78.1 & 100.1 & $\mathbf{1 3 . 3}$ & 64.2 & $\mathbf{8 . 6}$ \\
\hline 2010 & 1171.5 & 773.9 & $\mathbf{6 6 . 1}$ & 47 & $\mathbf{4 . 0}$ & 11.9 & $\mathbf{2 5 . 3}$ & 70.1 & 191.9 & 16.4 & 158.8 & $\mathbf{1 3 . 6}$ \\
\hline 2011 & 1405.5 & 954.6 & $\mathbf{6 7 . 9}$ & 64.4 & $\mathbf{4 . 6}$ & 17.5 & $\mathbf{2 7 . 1}$ & $\mathbf{7 2 . 5}$ & 282.2 & $\mathbf{2 0 . 1}$ & 104.5 & $\mathbf{7 . 4}$ \\
\hline
\end{tabular}

Albania exports to over 40 countries.

The first-place rank in Albanian exports is EU countries by $72.5 \%$ of total exports. So on account of exports, mainly to the price level, the Albanian economy is dependent on the economic situation of these countries. The application of these countries is higher than our economy is insensitive to them. So it is not normal to draw such a conclusion because if their demand for our goods is increased it will grow Albanian exports.

-In the second place come the Balkan countries by $20.1 \%$. Exports by main countries of export are:
1. Italy $53.2 \%$,
2. Turkey $7.6 \%$
3. Kosovo $7.4 \%$
4. Greece $5.1 \%$
5. Spain $3.5 \%$
6. Germany $2.9 \%$
7. Switzerland $2.7 \%$
8. China 2.5\%
9. Macedonia 2.1\%

Although in Italy there are exported $53.2 \%$ of total Albanian exports in its Trade Balance the name of Albania is not listed as a country that is considered in Italian imports. In Italy there are exported 747 million euros in absolute amount goods and services. Italian imports in USD for 2010 were 459.7 billion and main countries from where they have been imported are: Germany 16.68\%, France 8.82 percent, China 6,53 \%, Netherlands 5,63 \%, Spain 4,3\%, Russia 4, $12 \%$, Belgium $4,08 \%$ etc., (2009). As it is seen Albania exports $53.2 \%$ of total exports in Italy it does not appear at all in the main countries from which Italy imports. It is quite normal that the Albanian exports in Italian imports are accounted for only about 1/460 of them which allows us to draw the conclusion that despite the Italian economic recession it will not have any impact on the Albanian imports. This figure also includes goods imported for re-export.

In second place comes Turkey exports of which are increased significantly. From $2 \%$ in 2008 to $7.6 \%$ in 2011. Exports with Kosovo occupy second place after Italy with $7.4 \%$. This figure has remained unchanged for almost four years. Exports with Greece have fallen sharply which has shifted from the second to the fourth place. Spain and

\footnotetext{
${ }^{8}$ Surce. Banka of Albania. Statistical Report 10/2011. Monthly Statistical Report 02/2012

${ }^{9}$ Surce. Banka of Albania. Monthly Statistical Report 02/2013

10 Surce. Banka of Albania. Statistical Report 10/2011. Monthly Statistical Report 02/2012
} 
Switzerland exports have increased and exports of generally processed goods. Thirteen countries are in charge of exporting about $92 \%$ of the total. $68.7 \%$ of the total is exported to Italy, Greece, Montenegro, Macedonia and Kosovo, then in neighboring countries. The exported amount is is small enough so Macedonia Albania is not in the list of major importing countries. Given the size of Albanian exports and its structure we can conclude that even if european economy decreases this does not affect, as it has not affected the level of Albanian exports. Albanian producers have exported abroad in these years without any problem on account of recession of European countries.

\subsection{Countries from which imports goods Albania11:}

\begin{tabular}{|c|c|c|c|c|c|c|c|c|c|c|}
\hline Years & $\begin{array}{c}\text { Total in million } \\
\text { euro }\end{array}$ & $\begin{array}{c}\text { Countries of } \\
\text { EU }\end{array}$ & $\%$ & $\begin{array}{c}\text { Countries of EU (new } \\
\text { members) }\end{array}$ & $\begin{array}{c}\text { EU } \\
\text { total }\end{array}$ & $\begin{array}{c}\text { Balcan } \\
\text { countries }\end{array}$ & $\%$ & $\begin{array}{c}\text { Other countries of } \\
\text { the world }\end{array}$ & $\%$ \\
\hline 2008 & 3570.2 & 1928.3 & 54.0 & 240.0 & 6.7 & 60.7 & $\mathbf{5 1 1 . 5}$ & 14.3 & $\mathbf{8 9 0 . 3}$ & 24.9 \\
\hline 2009 & 3248.8 & 1849.4 & 56.9 & 238.5 & 7.3 & 64.3 & $\mathbf{4 2 3 . 5}$ & 13.0 & 737.4 & 22.7 \\
\hline 2010 & 3474.1 & 1965.1 & 56.6 & 284.7 & $\mathbf{8 . 2}$ & $\mathbf{6 4 . 8}$ & $\mathbf{5 1 2 . 8}$ & 14.8 & 711.5 & 20.5 \\
\hline 2011 & 3905.3 & 2223.7 & 56.9 & $\mathbf{2 7 4 . 6}$ & $\mathbf{7 . 0}$ & $\mathbf{6 4 . 0}$ & $\mathbf{5 5 7 . 4}$ & 14.3 & $\mathbf{8 4 4 . 7}$ & 21.6 \\
\hline
\end{tabular}

Albania imports of over 80 countries on all continents, from Australia, New Zealand, Thailand, China, USA, Mexico, Brazil, Argentina, Peru, Saudi Arabia, Iran, Russian Federation, EU, etc.. Its imports generally are performed with dollar and euro, but Albanian traders successfully use other currencies as well of different countries that are not included in the euro or the dollar area. Thus in countries of Russian Federation where over 180 thousand tons of wheat are imported, or in Ukraine where successfully is used dollar. In Croatia is used euro, in Turkey or China are used the dollar and euro by exchange rates. Albanian Importers are very familiar with exchange rates and operate in different markets that are using different currencies and have lower prices. So if wheat is imported from the Russian Federation, sugar is imported mainly from Brazil, oils from Hungary, Bulgaria, etc., clothing industry generally from Turkey and China, oil from Greece and Italy etc.. Diversification of imports has generally eliminated the effects of exchange rates and the effects of the recession in some countries of Western Europe. So the price level has been quite stable despite the quotas set in the references of Albanian customs. On their behalf we do not know precisely how much the prices have been or are the real incoming prices in Albanian territory to see the level of taxation through their customs tariffs. However it is important to say that this diversification has not affected negatively in the Albanian economy but it has had a positive impact on the contrary. So the Albanian economy in the field of imports from the global recession has not suffered a blow or shock in the offer or in the price level. This happened in 2008-2009 as well when was spoken generally of "food crisis" which in Albania passed as a balloon and was not felt in any product or in any period of time. It is true that there have been changes in exchange minerals that were exported from Albania to Macedonia and other European countries. This difference was not felt much to compute the amount of export growth.

The main share of imports in 2008, imports have been taken by Italian, Greek, Chinese, German and Turkish imports with $26 \%, 15 \%, 8 \%, 6 \%$ and $6 \%$ of total imports. With the exception of Turkey, imports of which have declined, imports from other countries increased by $15-30 \%$ by 2007 . The reports for the remain years are different.

From Italy 12 in 2011 imports accounted 30.7\%, 10.5\% of Greece, Germany 5.7\%, Turkey 5.5\%, Serbian 3.6\%, Austria 2.8\%, France 2.4\%, Spain 2.1\%, 1.6\% Macedonia, Croatia and Bulgaria by 1.3\%, Poland and England with the 1.1\%, 1\% Bosnia, Kosovo 0.9\%, China 6.3 Switzerland 2.6\%, Russian 2\%, USA 1.4 Ukraine 1.2\% etc..

If we analyze in detail the structure of Albanian imports we will see that the main part of the basket of goods is calculated based on the CPI (Consumer Price Index) is imported.

Growth and Structure of imports cause inflation in Albania generally the inflation to be imported and the Central Bank to affect in its' control.

\section{Classic-Keynesian Model and the Effect of Implementation of Macroeconomic Indicators}

From the theory we know that we have two macroeconomic models. Classic model and Keynesian model that rely on classical and keynesian school. When we talk about models in terms of restoring macroeconomic balances we are not

\footnotetext{
11 Surce. Banka of Albania. Statistical Report 10/2011. Monthly Statistical Report 02/2012

12 "Nominal 2009 GDP for the world and the European Union.". World economic outlook database, April 2010. International Monetary Fund. Retrieved 2010-04-21. RTT Neës. 2012-03-02. Retrieved 2012-04-09.
} 
handlimg with economic models under the privatization level of economic factors but with the aggregate market models and instruments applied by the government or by BQ to restore the economy in balance. Therefore, in this section we will talk about classical models and Keynesian not in terms of the degree of socialization, but in terms of market and the effects of government spendings in the economy. As conceived by the Albanian government and how should have been in fact conceived.

Classics. Classics assume their economic model regardless of the stage of the business cycle the economy is. Is it on a recession or is it located on economic growth, in peak or depressed, based on the spontaneous market forces. Classics accept the neutrality of money in the short term. The neutrality of money implies that the increase of money in circulation increased by an expansionist government policy will only affect the price variable and any other macroeconomic variable.

Classics assume that every time the economy is in equilibrium. This balance is spontaneously decided by market forces without government intervention. A government interference, according to their means increased spending on the free circulation associated with goods and services and consequently increasing the aggregate price level. Classics deny effective role of state intervention in the economy. In general terms do not have the type of ownership, but that means that we are dealing generally with private business where the role of the state is not directly felt. This role is seen only in public sector investment. So while the state can not invest in productive sectors each his expense only goes to increase spending "without effectively" without increased production. When we say without effectivity we understand directly and not indirectly effectively through the example of improvement of road infrastructure that affects private business. Specifically we analyze the Durres-Kukes road. For the construction of this road are spent about 1 billion euros. If 1 billion euros were spent in Durres-Kukes road would be used by private business would be set up with hundreds of businesses, would be employed thousands of people and this investment for 4-5 years would be repaid. In this case we would have, businesses long-term employment, long-term economic growth. So we can not expect any return ratio. In terms of transport growth it will have an impact on the economy but an effect that could not justify the expense. Spending cast in this way was carried out in euros and less in local currency.

The negative consequences of this government spending were: Paid currency left Albania because it was built with local firms. If it was built by local firms it will have an increase in imports and an increase in aggregate domestic demand. So we had an increase of money in circulation. In general out of this state investment economy had a lot of damage, deepening of the budget deficit, currency departure from the country, temporary employment, non-interference in the growth of aggregate demand, imports decline, the level of price impacts etc, etc..

Keynesians. Keynesians evaluate as positive the role of the state in the economy but they do so starting by the economic fluctation phase. So they evaluate when the economy is depressed. This theory was born precisely at the time of the Great Depression of the U.S. economy in 30 years. So this theoryshould function if the economy operates or is in recession or is depressed. Keynesians accept the neutrality of money in the longterm.

Keynesians have other concepts on the role of the state in the economy. Those starting by the great depression of the 30's in USA are of the view that state intervention in the economy brings not only increase of the aggregate price level but also economic growth. Assumption of the role of the state is just the growth of aggregate demand, thus stimulating the production indirectly through aggregate demand, and not through increased direct investment. So Keynesians' views since then are state estimated, and for our judgment is a more advanced view for the time when this school was born. While government spendings affected the growth of production then why not state property bring competing effectivity with private capital.

The Albanian state as an economic subject varies from Frenchman or German state because these countries do not have visible heritance of ownership because the capitalist state was a result of the feudal state created to protect the respective classes. So there was no duty or productivity function but stabilizing, regulatory, protective of the interests of certain classes. While the report is unlike that of state property inherited from socialism in all branches, in financial field, agriculture, industry, transport, tourism, etc..Albanian state had its chance to become very important player in the market. As in market goods, services and financial markets as well as in banks. But it took advantage of that opportunity.

Economic model applied in the Albanian economy is that of the total privatization. In this aspect the state property is completely ignored. In Albania, excluding large hydropower and a part of military firms everything else is privatized or is going towards privatization. In a not too distant future Albanian State will be stripped of all ownerships. There will be a possession only a few national forest park areas with some pastures, forests and nothing else. His motto is privatization builds capitalism, privatization brings development, privatization brings change, etc., and is completely ignored the role of state property and the state itself as a powerful agent market.

This applied model looks like in few places of Europe and of the world. This is because the other countries of 
Western Europe have leaked from feudalism to capitalism and socialism not of the economy. In these countries have mature markets and developed. We have the land market, housing market, capital market and have dominant financial capital. In Albania these markets or exist faulty or not exist at all.

In Albania there is still a genuine land market because it has not yet gone to the legitimate owner. Still Albanian Parliament is adopting laws relating to the ownership rights of former owners.

There is no housing market. Billions euros of capital is frozen for ten thousands of apartments are not privatized and have problems.

There is no capital market. In Albania the institution of scholarship is not recognized, while it also exists in small countries such as Montenegro.

There is financial capital. How should we understand this? In Europe, in developed countries like Germany, France, Italy, etc.there is the financial capital as an usual structure of their economies. Financial capital is representative in these countries as banking capital and industrial capital. Business in these countries is closely linked to banks. Banks have a major role in the development and growth of these countries and are considered as part of the business. So in these countries we have the relation:

- Depositor- Business- Bank - Industrial- Schoolarship.

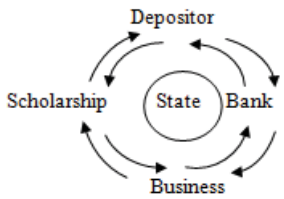

Business- Bank. Bank gives loans to business and has its own shares in the business. Business helds all accounts by the bank and all transactions conducts through it. Bank opens new horizons for other firms regarding the supply or sale. It lies near the business and then when it didn't created Liquidities seeing it as part of its function. So a lack of cash in the bank carries a blocking work in the business, and conversely a decline in business work. In this way in this regard have trasmission process.

Business- scholarship. Bank adds its capital through the stock trade as well. So it affects in the growth and development of businesses as well as business affects its expansion and in increasing of the participation of individuals in its contribute. So if the firm suffers a shock we will immediately have

its reflection in the stock market in the value of shares.

Depositor-bank-scholarship. Depositary which can be an individual, business or state is also associated with the bank or the stock market. With the bank it is indirectly related asd well as with business because bank depends precisely from business performance. It also depends on the performance of its stock exchange. So depositors are not just people who take an interest rate but are contributing to the development of the economy and general business.

The state is associated with the four subjects mentioned above.

In Albania there is no such triangle connection or it exists less. There is a simple connection to receive only the interest from giving a loan or receiving a savings deposit. Relationships between these entities are external, partial and nonessential, internal.

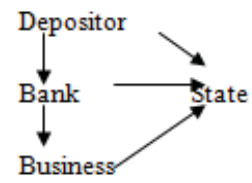

Namely the relationship between business and the bank is not essential because businesses in Albania are not related in an interior core way with banks. Not all actions are performed by banks. A good portion of themis directly performed in cash. So if a bank goes bankrupt businesses will simply lose as depositors. If the business goes bankrupt banks will not bankrupt but simply mark a subject with non-performing loans. Since it is not organically connected with the bank there is not a trasmission effect, so the phenomenon is isolated in a subject.

In the middle of this connection lies the state. It is legally regulating the relations between economic entities. American state was weighed in the 2008 recession in the United States with an initial grant of 780 billion USD that 
liberated American economy from the cramp. It is the state that initiates the opportunity to protect the deposits of depositors. It is the state that stands on the side of the banks affected in the return of loans from debtors.

Eastern European countries have almost the same system. But here's worth pointing out that the former eastern bloc countries have not had the degree of socialization of property as there was with Albania, contrary in those countries it also had private economy, the individual and private economy was known, particularly in agriculture. So in the process of privatization they were ready and didn't destroyed anything that had been built up in the 90's. Their socialism was more mature than Albanian extremist socialism. Enterprises and lands were privatized without any problems and gradually began to arise typical capitalist structures that in Albanian economy will probably take decades to build. If further we would compare the ownership structure of the Albanian economy with Chinese we can say that they have absolute differences. In China, state enterprises play an important role in the economy; occupy an important place in China's GDP. China thrives in all types of properties and all types of economic relations, at a time when in Albania we have only private properties and we privatize everything. The role of the state in China is crucial not only in making and implementing decisions but also in the economy. It is straightforward defense of its citizens through state property, which no longer exists in the economy. In this way the role of the state in Albania is limited simply to state-business relations and not directly state-citizen. Their relations are generally indirect come out of business.

\section{Effects of Policy Instruments in Terms of the Albanian Economic Model for the Realization of Macroeconomic Indicators}

Instruments that affect the implementation of macroeconomic indicators are of fiscal and monetary sphere applied respectively by central and local government as well as the Central Bank. Before the 90's Central Bank had the same tools available to influence the realization of macroeconomic indicators. Given that it operated in a centralized economy, one leveled applied a direct indicator, determining the credit limit, of the lower interest on deposits and overhead loans. After the 90's until 2000 when it completed the privatization of the Savings Bank it applied direct instruments for achievement of its own objectives. After the privatization of the Savings Bank was fully passed on the application of indirect monetary instruments. Three policy instruments were used, first, the mandatory reserve rate that went with $10 \%$ deposit, the second, open market operations, in the trading of securities and the third a rate of financing commercial banks of the second level. Bank policies focused mainly on the implementation of the close strategic objectives. Its main objective has been and remains "the achievement and maintenance of price stability". This objective is consistent with the strategic objective of the European Central Bank. At first glance it is a normal target but if we analyze the situation and objectives of the economies of Western Europe with the Albanian economy it looks like this objective in Albania's target is not complete. As a main objective besides indicators of inflation it should be the growth and decline of the unemployment rate to its natural levels. These objectives and maintaining of the exchange rate from unfair competition have been a second-handed or third-handed targets.

We mention this because the central bank's role in addressing the economic imported phenomena is especially important in an economy as Albanian economy where we have a generally imported inflation.

Besides the Central Bank an important role in achieving macroeconomic indicators have the applicable fiscal policies of the Albanian Government. Their role is, as the Central Bank, to increase or decrease the quantity of money in circulation, but unlike the Central Bank government uses instruments of other fiscal nature. So it can operate at the level of the tax increase, reduce or increase their new taxes, on the one hand and on the other hand it can increase operating costs for different projects or simply to increase the level of salaries and pensions.

Below you will see how these policies are implemented in terms of the Albanian economy, especially as they were implemented in the period of global recession. I'Il avoid the role of monetary policy because their analysis is the subject of another study.

\section{Effects of Fiscal Policy in Albanian Economy}

Albanian governments from 2000 to 2008 have attained a normal economic growth, with an average of $5 \%$. With the start of the downturn in 2008, the government in power should have been reflected in its policies on both aspects of fiscal policy, both in terms of taxation and spendings. More attention should be devoted to its revenue policies regarding salaries and pensions. In 2009 it sought to tax revenues increase by as much as 1 billion euros as they were raised in 2008 compared with 2007. Such an increase was not possible for many reasons, one of which was that 2009 was an election year for central government. Government in 2008 worked in several ways to increase revenue up to 1 billion 
euros. So significantly increased the number of unregistered taxpayers. It was revalued the size of businesses including a large part of them as a subject of VAT, it was changed the tax rate and were settled some new.

Objectives that were set for the prospects were clearly higher. Specifically we will mention some of them:

\begin{tabular}{|c|c|c|c|c|c|c|c|}
\hline \multicolumn{8}{|c|}{ Main macroeconomic indicators ${ }^{13}$} \\
\hline \multicolumn{8}{|c|}{ Mainmacroeconomic indicators ${ }^{16}$} \\
\hline Indicators & 2007 & 20082 & 2009 & 2010 & 2011 & 2012 & 2013 \\
\hline Inflation(average) $\%$ & 2.9 & 3.4 & 2.2 & 3.0 & 3.0 & 3.0 & 3.0 \\
\hline Real growth of GDP $\%$ & 6.0 & 8.0 & 3.0 & 5.5 & 6.5 & 7.1 & 6.7 \\
\hline Unemployment rate \% & 13.2 & 12.7 & 12.7 & 12.1 & 10.8 & 9.7 & 8.6 \\
\hline Market balance & -26.7 & -26.7 & -24.7 & -23.3 & -21.7 & -21.2 & -19.9 \\
\hline \multicolumn{8}{|c|}{ (Goods \& Services) $\%$ of GDP } \\
\hline \multicolumn{8}{|l|}{ billion lek } \\
\hline In $\%$ to GDP & 26.8 & 26.4 & 29. & & 26.6 & 26.8 & 27.1 \\
\hline TOTAL OF & 351,492 & 410,721 & & 331 & 408,135 & 449,523 & 3497,130 \\
\hline \multicolumn{8}{|l|}{ COSTS, billion lek } \\
\hline$\%$ to GDP & 32.4 & 33.0 & & 30.6 & 29.9 & 29.9 & 30.0 \\
\hline DEFICIT $\%$ to GDP & -5.5 & -4.0 & & -4.0 & -3.2 & -3.0 & -3.0 \\
\hline
\end{tabular}

As it can be seen aim of these provisions is to ensure a normal economic growth in relation to its neighbors and countries where Albania has economic trade relations. Reduce the unemployment rate to its natural rate, to maintain a stable level of inflation and pleasing, to increase the budget revenues and reduce costs, decrease debt and fiscal deficit, trade deficit decrease etc.. The government's decision is ambitious in relation to the possibility that has the Albanian economy, but impossible to realize. Only the unemployment rate was intended to lie unexploited from $13.2 \%$ to $9.7 \%$ in 2012 or $3.5 \%$. If we refer to the actual growth figures from 2000 to 2008, taking into account Okunit law, the unemployment rate should have reached the time in its natural rate. But in fact this did not happen. The figures show that the decline in unemployment is very low figure. Namely economic growth and the unemployment rate for these years has been:

\begin{tabular}{|c|c|c|c|c|c|c|c|c|c|}
\hline & 2000 & 2001 & 2002 & 2003 & 2004 & 2005 & 2006 & 2007 & 2008 \\
\hline Economic growth \% & 6.7 & 7.9 & 4.2 & 5.8 & 5.7 & 5.7 & 5.4 & 6.0 & 7.8 \\
\hline Unemployment rate & 16.8 & 16.4 & 15.8 & 15.0 & 14.4 & 14.1 & 13.8 & 13.5 & 13.2 \\
\hline
\end{tabular}

In eight years, the unemployment rate decreased only for 3.6\%. But we shouldn't forget that in 1996 the unemployment rate was $12.3 \%$. The average GDP growth is 6:15\% and Np has fallen only $3.6 \%$. In fact should fall to $(6.15-3) / 2=$ $1.57 \%$ per year for 9 years and we had a drop of 14:13\%. So by Okuni law the unemployment rate in 2009 had to be only $2.67 \%$.

Taking the above data into account predictions were not needed because they had not a strong real accomplishment. This is the main reason why they did not materialize. Factual data for these indicators have given in this paper but the following are some other data in the fiscal balance.

No indication was implemented according to the Government, contrary to it all have been deteriorated since the first indicator, the indicator to inflation and budget deficit. Below are some key data for fiscal indicators achieved in these years.

Fiscal indicators according to consolidate budget ${ }^{14}$ in billion lek

\begin{tabular}{|c|c|c|c|c|c|c|c|c|c|}
\hline & $\begin{array}{c}\text { Total of } \\
\text { income }\end{array}$ & $\begin{array}{c}\text { Total of } \\
\text { costs }\end{array}$ & Deficit & $\begin{array}{c}\text { External loan in billion } \\
\text { euros }^{15}\end{array}$ & $\begin{array}{c}\text { External loan in } \\
\text { billion ALL }\end{array}$ & $\begin{array}{c}\text { Internal } \\
\text { loan }\end{array}$ & $\begin{array}{c}\text { Total } \\
\text { loan }\end{array}$ & $\begin{array}{c}\text { In\% towards } \\
\text { GDP }\end{array}$ & $\begin{array}{c}\text { GDP } \\
\text { nominal }\end{array}$ \\
\hline 2008 & 291,238 & 351,492 & $-60,254$ & $\mathrm{x}$ & 195.4 & 400,456 & 595,856 & $\mathbf{5 4 . 7}$ & $1,089,293.1$ \\
\hline 2009 & 298,981 & 379,863 & $-80,883$ & $\mathrm{X}$ & 267.5 & 415,028 & 682.529 & $\mathbf{5 9 . 3}$ & $1,151,019.6$ \\
\hline 2010 & 324,721 & 362,752 & $-38,031$ & $1,886.0$ & 308.0 & 407,372 & 715.372 & $\mathbf{5 7 . 8}$ & $1,242,418.0$ \\
\hline
\end{tabular}

${ }^{13}$ The decision of the council of ministers no.4, date 7.1.2010 for approval of the macroeconomic and fiscal framework, for the period 2011-2013

${ }^{14}$ Monthly statistic report. Bank of Albania. updated 6.03.2012. Fiscal indicators based on consolidated budget 2011. Table 1. 2a progressive. Ministry of finances 2012

${ }^{15}$ Monthly statistic report. Bank of Albania. updated 6.03.2012. Fiscal indicators based on consolidated budget 2011. Table 1. $2 a$ progressive. Ministry of finances 2012 


\begin{tabular}{|l|c|c|c|c|c|c|c|c|c|}
\hline 2011 & 330,475 & 376,352 & $-45,877$ & $2,069.1$ & 333.9 & 438,582 & 772.482 & $\mathbf{5 8 . 7}$ & $1,316,000.0^{16}$ \\
\hline 2012 & 330.4 & 376.2 & -45.9 & $2,223.6$ & 357.6 & 470.4 & 828 & $\mathbf{6 3 . 2}$ & $1,310,126.5^{17}$ \\
\hline
\end{tabular}

Why has this happened? This has happened because of unfair policies applied in the field of monetary and fiscal policies of the Government and the Central Bank, but mostly by the Economic Model applied in this economy.

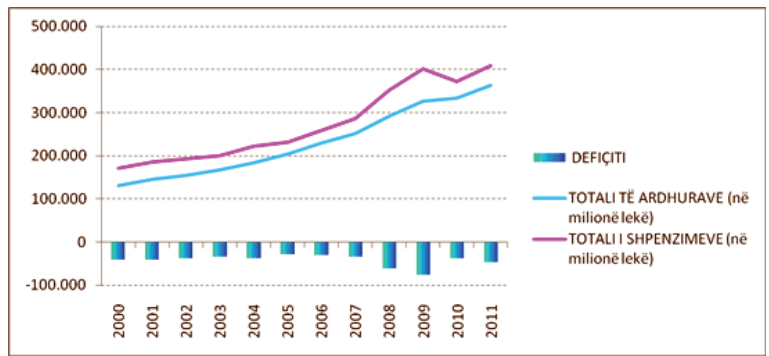

According to the Ministry of Finances we have this situation:

The structure of public loan during 201118

The level of Total stock of the public loan for 2011is around 772 billion lek (58.76\% i PBB-së) or $8 \%$ higher than a year before. Stock of Internal Public loanfor 2011 is 439billion lek or around 7.66\% more than in 2010, while Stock of External public loan is 334biullion lek or $8.37 \%$ more compared with one year before.

The level of internal loan is still high and takes around 33,36\% of the Internal Gross production (PBB)during 2011 compared to the level of external loan that consists $25.39 \%$ of PBB.

Data is given as follows:

$\begin{array}{lcccc}\text { Year } & 2008 & 2009 & 2010 & 2011 \\ \text { Total loan stock } & 595,883 & 682,546 & 715,371 & 772,364 \\ \text { Internal loan stock } & 400,456 & 415,028 & 407,372 & 438,582 \\ \text { External loan stock } & 195,427 & 267,518 & 307,999 & 333,782 \\ \text { GDP } & 1,089,293 & 1,151,020 & 1,238,093 & 1,314,702 \\ \text { Total loan stock/GDP } & 54.7 \% & 59.3 \% & 57.78 \% & 58.75 \% \\ \text { Internal loan stock/GDP } & 36.76 \% & 36.06 \% & 32.9 \% & 33.36 \% \\ \text { External loan stock/GDP } & 17.94 \% & 23.24 \% & 24.88 \% & 25.39 \%\end{array}$

The graph gives a clear sight of the level of the internaland external loan stock through years .

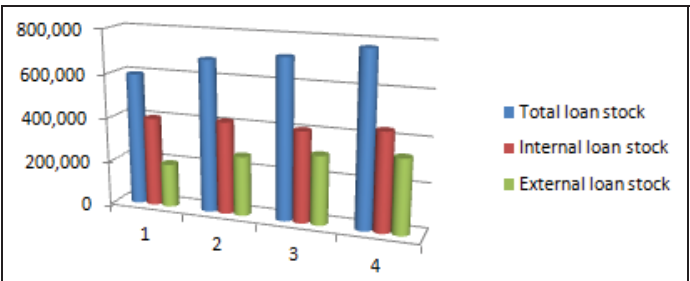

Theoretically growth opportunities in a particular place are seen at the combination of fiscal and monetary policies coordinating with foreign lending, but increasingly relying measured in real state of the economy. Government since 2007 and up to date has attempted to apply expansionary fiscal policy. Central Bank monetary policy has applied moderate monetary policies, symbolic and expansionary without any impact on the live of the Albanian economy (analysis of the role of $\mathrm{BQ}$ will be done in another study).

${ }^{16}$ Prediction of economic growth $6 \%$.

17 Prediction

${ }^{18}$ Source: Ministry of Finances. Coment and Analisis: Open Data Albania (ODA) 
The government has increased the level of spendings on two aspects:

The level of operating expenses, salaries and pensions for each year in proportion not justifiable in relation to real economic growth.

It has increased the level of spendings on infrastructure investment without relying on internal funding opportunities but relying on credit, relying on debt regardless of what those conditions will be realized.

For the first group that increased spending has not been necessary to do so for every year. This should be done only if there is real economic growth, of GDP not of consumption of G, from government investments and NX but from business investments. Their growth affects negatively more than positively on the economy because their spendings provoke an increase in aggregate demand on the component $\mathrm{C}$, while this costs are drawn out of business that can be used for increasing productive investments.

The costs of the second group are expenses that do not directly affect the economic growth but indirectly affect on a longterm. In these types of expenses it has several problems, among which we will mention.

Expenditures in the form of investments not in sectors that directly produce goods and services. They are investments that improve the conditions and speed up processes affecting in particular investment in the road infrastructure.

The deadline for their return can not be calculated precisely, but even if it is, it is considered too long. In simple economic terms they are not effective. So if we just see the road Durres- Kukes in relation to hundreds of businesses that could be raised by 1 billion euros then we would have an absolute difference. Business for 5-6 years would pay its investments and would return the money in circulation, while road and other roads and traffic facilities only create higher volume but they do not produce and employ in such periods. One of the reasons for the collapse of the Greek economy were precisely investments in these areas, in infrastructure.

In the investment in the public sector we have the tendering process that is an opportunity to abuse the funds. In Albania we have dozens of cases of abuses whith tenders which are publicly announced by the Control of the Supreme State.

From the data presented it is clear that spending policies have been expansionary in all years. It is intended that by taking debts in the form of loans, sale of Eurobonds or trading of treasury bills held the financial situation normal by providing an economic growth in terms of coping with the impacts that could give the global recession. This action has led to significantly increased costs by increasing the deficit and debt in general. The increase of debt as a percentage and absolute amount is not justified by the percentage of growth or by improving other indicators. It is targeted the increase of salaries and pensions considering the move as an increase of welfare of the people, in fact, such action has been mostly an electoral show then a real increase in salaries or welfare. We are not mentioning the low rates of growth in absolute numbers or drastic cuts that show that we are dealing with hardly studied actions.

Another reason that should be taken into consideration is that the economies of the type models of Albanian nature of fiscal policy effects are short-lived. Neutrality is not just money in the long run but in the short term. So they affect a boost aggregate demand without affecting the growth of manufacturing costs. They affect the enhancing effect of corrugation of private investment or effect "croweding out". Government investment that are to addressed to economy in general go on road infrastructure, and little or not at all in a number of other strategic sectors. Sewage in one direction has its benefits but mostly it has weaknesses that have a direct negative impact on economic growth as it has affected the Albanian economy.

One of the reasons to avoid the appreciation of its impact on the economy and its concentration mainly in the hands of the state is the flow of two other currencies, the euro and the dollar. The analysis of these coins in circulation in Albanian economy notes that most of the loans are foreign rather than domestic. The reasons why loans are getting more in foreign currency then in lek are much lower then the interest rates of loans in domestic currency.

So the biggest deposits in lek and less loans in lek have made ALL the banks to have a lek state in the Second Level. This situation is not freely withdraw from creditors it is withdraw from the Government through the trading of Treasury Bills. This "croŵding out" situation of having the condition rate as deposit- loan margin should affect the rate of decline in Treasury Bills. In fact it didn't happen such a phenomenon, contrary the level of interest rates of Treasury Bills reached up to $9 \%$. This has not only considered as the reasons for increasing the Government's request to have cash but also as a result of a silent agreement of commercial banks to buy government bonds.

In this way not control the interest rate of commercial banks by the Central Bank has influenced and will continue to increase the cost of government deficit and debt. And it is precisely due to the privatization of all banks operating within the territory of the Republic of Albania. 


\section{Conclusions}

The privatization of the Albanian economy is moving from one extreme to another, from $100 \%$ state - owned properties to $100 \%$ private properties. This privatization has choked economy losing an important economic factor as the state. The government has lost control in strategic sectors such as banking field, fuel field, mobile power, military products etc..

Lack of strategic productive sectors has turned the spending into inefficient.

Recession of European economies and generally the global had little impact on the economy. The biggest impact has been on the decline in remittances.

The collapse of the Albanian economy and deficit around 60\% of GDP are the result of the Albanian economic model implemented by the Albanian government.

Fiscal policies have been highly expansionary and irrelevant on conditions that were passing the Albanian economy. These policies were applied after 2008 and should have been applied now, not so aggressive. Their effect is only short term and not long term. This is a reason to suppress the progress of the Albanian economy.

Monetary policy is not adapted to fiscal policies consequently because of their impact on economic growth in Albania has been no apparent weight.

\section{Recommendations}

- To reassess the public-sector

- To curb the privatization of strategic sectors and ristate those that performed without efficiency.

- To establish the Agricultural Bank of Tourism with fully state owned capital.

- Central Bank to fully apply expansionary monetary policy following the example of the European Central Bank.

- Not to be seen the reduction of debt in curbing of budget expenditures but rather on economic growth.

\section{References}

Statistical Report. November 2009. Tirana. Bank of Albania.

Statistical Report. April 2010. Tirana. Bank of Albania.

Statistical Report. April 2011. Tirana. Bank of Albania.

Monthly Statistical Report. 10/2011. Bank of Albania 2011.

Statistical Report. April 2012. Tirana. Bank of Albania.

Statistical Report. 03/2013. Tirana. Bank of Albania.

Statistical Report. 02/2012. Tirana. Bank of Albania.

Statistical Report. 10/2012. Tirana. Bank of Albania.

Statistical Yearbook Of Albania 1991. Ministry Of Economy. Department Of Statistics

Statistical Yearbook. Ministry of Agriculture 2009. MBUK. Statistical Yearbook 1976.

Figures In Albania.2010. INSTAT

Alqi Naqellari. Model economic and agricultural development challenges. Albanian Journal. 29.04.2010

Financial Stability Report on The First 6 months of the year 2011. Bank of Albania 2011

Philip Gerson. "The Impact of Fiscal Policy Variables on Output Growth" IMF Working Paper WP/98/1. www.imf.org

The statisticsof Foreing Trada are taken from http://www.instat.gov.al

Naqellari A. 2004, Principles of Economics, Tirana Dardania (ed)

Mancellari A., Haderi S., Kule DH., \& Qirici S.2002, Principles of Economics, Tirana, Pegi (ed)

Antonelli G.,Cainelli G., De Liso N., Leoncini R. \& Montresor S. 2007, Economia,Torino G. Giappichelli (ed)

Mehilli T., Xhafa K., Naqellari A., Demo E., "The Influence of Financial System in Albanian Economy" Book of Proceedings, $2^{\circ}$ International Conference on Human and Social Sciences ICHSS 2012 - March 23-24, 2012, Tirana, Albania Volume 2, pg. 9 http://www.mcser.org/images/stories/4_conferences/ICHSS_2012/volume\%202.pdf

The Fifth International Scientific Conference "Investment in the function of economic development and integration processes". Ulcinj april 2013. "Financial system and its impact on the Albanian economy". Alqi Naqellari \&Guximtar Rushani.

Naqellari.A." The negative Consequences of the Restructuring of the Albanian Banking System since the 90-s" Pg. 435-447. Mediterranean Journal of Social Sciences. Vol. 4,No.6,July 2013.

Naqellari.A."Macro-economic model of aggregate market in Albanian economy and relevant problems thereto". Iliria International Revieŵ. Issue 2/2011. Kosovo. Pages 14. ISSN 2192-7081. no-co. 